\title{
Effect of Residential Street Speed Limit Reduction on Driving Speeds in Portland, Oregon
}

\author{
Jason C Anderson ${ }^{1}$ (D), Christopher Monsere ${ }^{1}$ (D), Sirisha Kothuri ${ }^{1}$ (D) \\ ${ }^{1}$ Civil and Environmental Engineering, Portland State University \\ Keywords: speed reduction, driver behavior, regression, logit model, vehicle speeds \\ https://doi.org/10.32866/001c.31956
}

Findings

This study analyzed the impacts on motor vehicle observed speeds following a residential speed limit reduction from $40.23 \mathrm{~km} / \mathrm{hr}(25 \mathrm{mi} / \mathrm{hr}$ ) to $32.19 \mathrm{~km} / \mathrm{hr}$ $(20 \mathrm{mi} / \mathrm{hr})$ in Portland, OR that was accompanied by a public awareness and signage campaign. The study used before and after observations of vehicle speeds collected by pneumatic tube traffic counters. Overall, the analysis suggests that the reduction of posted speed limits to $32.19 \mathrm{~km} / \mathrm{h}(20 \mathrm{mi} / \mathrm{h})$ has resulted in lower observed vehicle speeds and fewer vehicles traveling at higher speeds. The reduction in the percentage of vehicles traveling above $48.28 \mathrm{~km} / \mathrm{h}(30 \mathrm{mi} / \mathrm{h})$ $(-1.7 \%)$ and $56.33 \mathrm{~km} / \mathrm{h}(35 \mathrm{mi} / \mathrm{h})(-0.5 \%)$ are larger in magnitude than other speed metrics.

\section{Questions}

1. Was there a statistically significant change in mean speed, 85th percentile speed, and proportions of vehicles traveling greater than $40.23 \mathrm{~km} / \mathrm{hr}(25 \mathrm{mi} / \mathrm{hr}), 48.28 \mathrm{~km} / \mathrm{hr}(30 \mathrm{mi} / \mathrm{hr})$, and $56.33 \mathrm{~km} /$ hr $(35 \mathrm{mi} / \mathrm{hr})$ after the residential speed limit reduction was implemented and the accompanying public awareness and signage campaign?

2. What is the estimated effect of the speed limit change on observed vehicle speeds?

\section{Methods}

The Portland City Council approved an ordinance reducing the speed limit on all residential streets to $32.19 \mathrm{~km} / \mathrm{hr}(20 \mathrm{mi} / \mathrm{hr})$ in January 2018. A residential street is a street that is in a residence district according to Oregon Law ORS 801.430 and has a statutory speed limit. Collector and arterial classifications are not included. The $32.19 \mathrm{~km} / \mathrm{hr}(20 \mathrm{mi} / \mathrm{hr})$ speed limit went into effect on April 1, 2018. The city installed new speed limit signs and updated existing signs over the period of February 2018 to May 2019. The final $32.19 \mathrm{~km} / \mathrm{hr}(20$ $\mathrm{mi} / \mathrm{hr}$ ) sign installation increased the number of residential speed limit signs from fewer than 1,000 signs to more than 2,000. An educational and awareness campaign " 20 Is Plenty" was also conducted, as well as media campaigns. As part of the effort, nearly 7,000 yard signs were distributed to residents.

Data was collected by the Portland Bureau of Transportation at 58 locations on residential streets using pneumatic tubes placed perpendicular to the direction of traffic flow. Before data was collected between 2013 and 2018, while all after data was collected between February 2019 and July 2019. Both before 
and after data were collected during weekdays and a few weekends, with the duration varying between 24-97 hours at each location. Recorded speeds of $0 \mathrm{~km} / \mathrm{hr}$ or greater than $160.93 \mathrm{~km} / \mathrm{hr}(100 \mathrm{mi} / \mathrm{hr})$ were removed from the data prior to analysis for quality control. The excluded data, as a percentage of total observations, was consistent across the two periods (approximately $8 \%$ ). After cleaning, 131,452 before and 82,768 after observations were available for analysis. All analyses were conducted using the disaggregate, or raw, speed data.

Available controlling factors included time-of-day, day of the week, vehicle classification, and data extracted from Portland's GIS database on physical and operational aspects of the roadway (curb-to-curb pavement width, number of lanes, presence of sidewalks, curb height, presence of parking signs, and pavement condition). A summary of available controlling factors is given in Table 1.

\section{Findings}

Descriptive statistics for the pooled data (all sites) and each site were computed to assess changes in common speed measures. Mean speed increased from 34.76 $\mathrm{km} / \mathrm{hr}(21.6 \mathrm{mi} / \mathrm{hr})$ to $34.92 \mathrm{~km} / \mathrm{hr}(21.7 \mathrm{mi} / \mathrm{hr})(0.37 \%$ increase). This change was statistically significant due to the large sample size but is not a practically significant change. Median speed and 85th percentile speed remained the same. The percentage of vehicles traveling with speeds greater than $40.23 \mathrm{~km} / \mathrm{hr}(25$ $\mathrm{mi} / \mathrm{hr}), 48.28 \mathrm{~km} / \mathrm{hr}(30 \mathrm{mi} / \mathrm{hr})$, and $56.33 \mathrm{~km} / \mathrm{hr}(35 \mathrm{mi} / \mathrm{hr})$ all decreased. The percentage of vehicles with speeds greater than:

- $40.23 \mathrm{~km} / \mathrm{hr}(25 \mathrm{mi} / \mathrm{hr})$ decreased by $0.5 \%$

- $48.28 \mathrm{~km} / \mathrm{hr}(30 \mathrm{mi} / \mathrm{hr})$ decreased by $1.7 \%$

- $56.33 \mathrm{~km} / \mathrm{hr}(35 \mathrm{mi} / \mathrm{hr})$ decreased by $0.5 \%$

All differences were statistically significant with $95 \%$ confidence.

At the 58 individual sites, changes in speed measures vary by location. As shown in Figure 1, at 33 sites (56.9\%) there was a decrease in mean speed, at 43 sites $(74.1 \%)$ a decrease in median speeds, and at 50 sites $(86.2 \%)$ a decrease in 85th percentile speed. Decreases were also observed for the percentage of vehicles traveling faster than $40.23 \mathrm{~km} / \mathrm{hr}(25 \mathrm{mi} / \mathrm{hr})(74.1 \%), 48.28 \mathrm{~km} / \mathrm{hr}$ $(30 \mathrm{mi} / \mathrm{hr})(69.0 \%)$, and $56.33 \mathrm{~km} / \mathrm{hr}(35 \mathrm{mi} / \mathrm{hr})(72.4 \%)$. Spatial patterns were also investigated, but no apparent spatial patterns among speed changes were present.

Figure 2 shows mean speed changes using a bar plot, sorted by the magnitude of change. Changes in mean speed range from a decrease of $5.63 \mathrm{~km} / \mathrm{hr}(3.5$ $\mathrm{mi} / \mathrm{hr}$ ) to an increase of $3.86 \mathrm{~km} / \mathrm{hr}(2.4 \mathrm{mi} / \mathrm{hr})$. The average decrease was 2.25 $\mathrm{km} / \mathrm{hr}(1.4 \mathrm{mi} / \mathrm{hr})$ and the average increase $1.13 \mathrm{~km} / \mathrm{hr}(0.7 \mathrm{mi} / \mathrm{hr})$. Figure 3 
Table 1. Summary of Potential Controlling Explanatory Variables

\begin{tabular}{|c|c|c|c|c|c|}
\hline Variable & Frequency & Mean & St. Dev. & Minimum & Maximum \\
\hline \multicolumn{6}{|l|}{ After Speed Reduction Indicator } \\
\hline 1 if after speed reduction, 0 if before & 82,768 & 0.386 & 0.487 & - & - \\
\hline \multicolumn{6}{|l|}{ Speed Bins } \\
\hline 1 if greater than $40.23 \mathrm{~km} / \mathrm{hr}(25 \mathrm{mi} / \mathrm{hr}), 0$ otherwise & 51,262 & 0.239 & 0.427 & - & - \\
\hline 1 if greater than $48.28 \mathrm{~km} / \mathrm{hr}(30 \mathrm{mi} / \mathrm{hr}), 0$ otherwise & 12,536 & 0.059 & 0.235 & - & - \\
\hline 1 if greater than $56.33 \mathrm{~km} / \mathrm{hr}(35 \mathrm{mi} / \mathrm{hr}), 0$ otherwise & 1,953 & 0.009 & 0.095 & - & - \\
\hline \multicolumn{6}{|l|}{ Time-of-Day Indicators } \\
\hline 1 if 6:00 a.m. to $10: 00$ a.m., 0 otherwise & 69,259 & 0.323 & 0.468 & - & - \\
\hline 1 if $10: 00$ a.m. to $4: 00$ p.m., 0 otherwise & 47,821 & 0.223 & 0.416 & - & - \\
\hline 1 if 4:00 p.m. to $8: 00$ p.m., 0 otherwise & 3,752 & 0.018 & 0.131 & - & - \\
\hline 1 if $8: 00$ p.m. to $6: 00$ a.m., 0 otherwise & 93,388 & 0.436 & 0.496 & - & - \\
\hline \multicolumn{6}{|l|}{ Day-of-Week Indicators } \\
\hline 1 if Monday, 0 otherwise & 21,219 & 0.099 & 0.299 & - & - \\
\hline 1 if Tuesday, 0 otherwise & 40,592 & 0.189 & 0.392 & - & - \\
\hline 1 if Wednesday, 0 otherwise & 49,528 & 0.231 & 0.422 & - & - \\
\hline 1 if Thursday, 0 otherwise & 57,468 & 0.268 & 0.443 & - & - \\
\hline 1 if Friday, 0 otherwise & 29,524 & 0.138 & 0.345 & - & - \\
\hline 1 if Weekend, 0 otherwise & 15,889 & 0.074 & 0.262 & - & - \\
\hline \multicolumn{6}{|l|}{ Vehicle Classification Indicators } \\
\hline 1 if motorcycle/bike, 0 otherwise & 7,362 & 0.034 & 0.182 & - & - \\
\hline 1 if passenger vehicle, 0 otherwise & 166,130 & 0.776 & 0.417 & - & - \\
\hline 1 if 2 -axle long, 0 otherwise & 29,655 & 0.138 & 0.345 & - & - \\
\hline 1 if bus, 0 otherwise & 6,737 & 0.031 & 0.175 & - & - \\
\hline \multicolumn{6}{|l|}{ Roadway Characteristics } \\
\hline Surface width (m) & 214,220 & 9.370 & 1.205 & 5.486 & 12.192 \\
\hline Pavement condition index & 214,220 & 58.189 & 14.794 & 13 & 100 \\
\hline Curb height (cm) & 214,220 & 10.391 & 4.039 & 0 & 17.780 \\
\hline \multicolumn{6}{|l|}{ Adjacent Signage } \\
\hline 1 if no parking sign, 0 otherwise & 44,231 & 0.206 & 0.405 & - & - \\
\hline 1 if stop sign, 0 otherwise & 71,523 & 0.334 & 0.472 & - & - \\
\hline \multicolumn{6}{|l|}{ Pavement Type } \\
\hline 1 if composite pavement, 0 otherwise & 13,867 & 0.065 & 0.246 & - & - \\
\hline 1 if flexible pavement, 0 otherwise & 182,398 & 0.851 & 0.356 & - & - \\
\hline 1 if OILMa pavement, 0 otherwise & 9,390 & 0.044 & 0.205 & - & - \\
\hline 1 if rigid pavement, 0 otherwise & 8,565 & 0.040 & 0.196 & - & - \\
\hline
\end{tabular}

${ }^{a}$ OILM defined as Oil-Macadam Pavement Streets

shows the change in percentage of vehicles traveling faster than $48.28 \mathrm{~km} / \mathrm{hr}$ $(30 \mathrm{mi} / \mathrm{hr})$. These changes range from a decrease of $29.5 \%$ to an increase of $4.4 \%$. The average decrease was $3.8 \%$ and the average increase $0.8 \%$.

A series of statistical models were developed to determine the effects of the speed limit reduction while controlling for other available factors. An indicator variable ( 1 if after reduction, 0 if before) was created to estimate the effects of the reduction. 

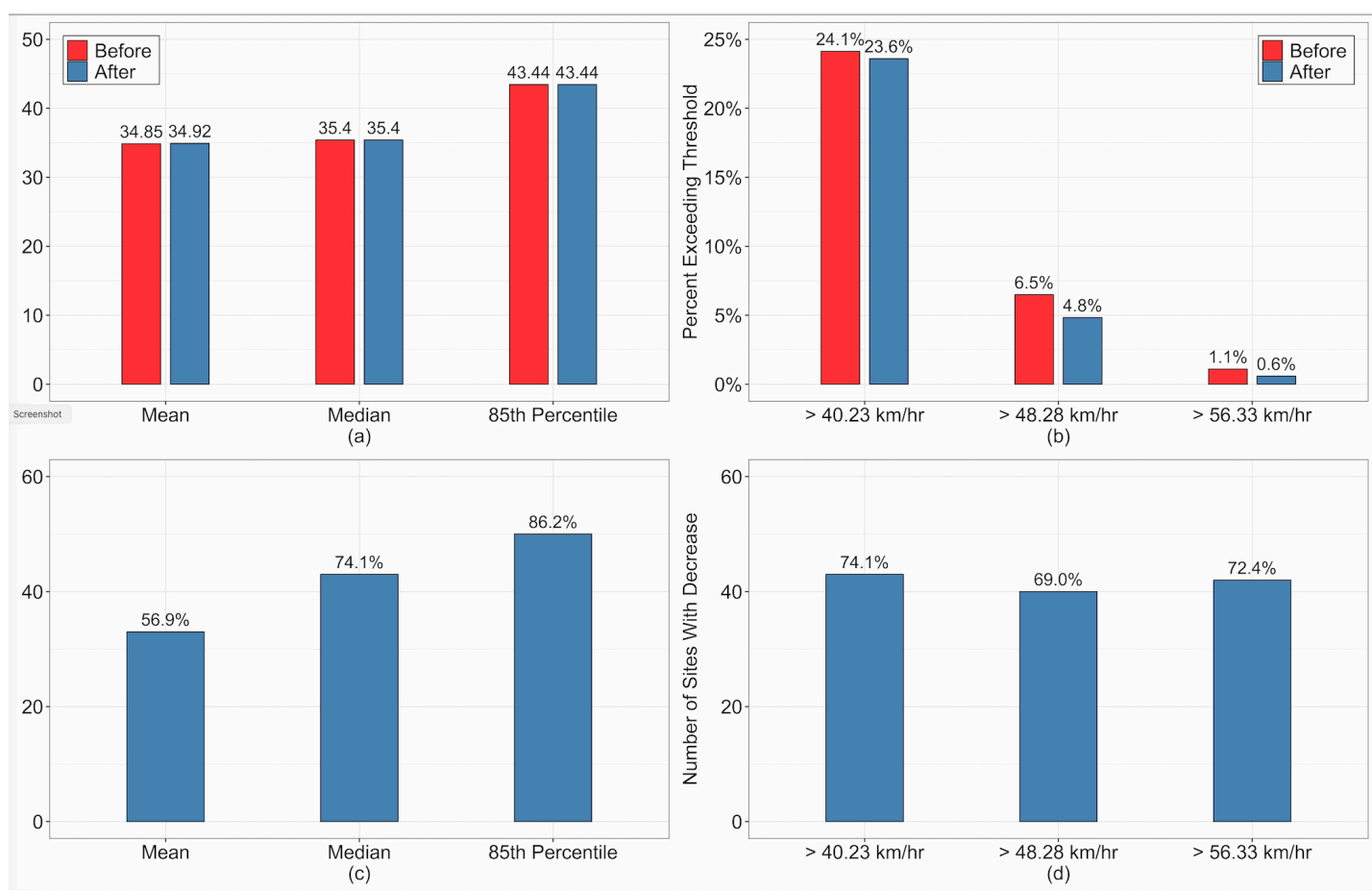

Figure 1. (a) Difference in mean, median, and 85 th percentile speed, (b) Difference in speeds of greater than $40.23 \mathrm{~km} / \mathrm{hr}$ $(25 \mathrm{mi} / \mathrm{hr}), 48.28 \mathrm{~km} / \mathrm{hr}(30 \mathrm{mi} / \mathrm{hr})$, and $56.33 \mathrm{~km} / \mathrm{hr}(35 \mathrm{mi} / \mathrm{hr})$, (c) Number of sites with decrease in mean, median, and 85 th percentile speed, and (d) Number of sites with decrease in speeds of greater than $40.23 \mathrm{~km} / \mathrm{hr}(25 \mathrm{mi} / \mathrm{hr}), 40.28$ $\mathrm{km} / \mathrm{hr}(30 \mathrm{mi} / \mathrm{hr})$, and $56.33 \mathrm{~km} / \mathrm{hr}(35 \mathrm{mi} / \mathrm{hr})$

Final model specifications for the log-linear regression model are shown in Table 2. The estimate for the after-reduction indicator indicates an expected decrease in observed speed of approximately $1.0 \%$, on average. The parameter is significant with well over $99 \%$ confidence. This expected decrease is about 3 -times greater than the $0.30 \%$ observed by $\mathrm{Hu}$ and Cicchino (2020) in a similar study.

Model results align with expectations regarding vehicle speeds. Street width is associated with higher speed (Fitzpatrick et al. 2001). Curb height is likely associated with on-street parking and contributes to narrow available travel way (decrease in speed). Pavement quality and ride are likely to be related to vehicle speed, but the literature is sparse. Previous studies have also found that speeds were less on weekends (Bornioli et al. 2018; Giles 2004).

Binary logit model specifications for the three speed thresholds are shown in Table 3. Parameter estimates, in absolute value, increase as the speed thresholds increase. For the after reduction indicator, the change in odds increases in magnitude as the speed threshold increases. The parameter estimate for after the speed limit reduction suggests a $15.9 \%$ reduction in odds of observing speeds greater than $40.23 \mathrm{~km} / \mathrm{hr}(25 \mathrm{mi} / \mathrm{hr})$, a $33.6 \%$ reduction in odds of observing speeds greater than $48.28 \mathrm{~km} / \mathrm{hr}(30 \mathrm{mi} / \mathrm{hr})$, and a $49.6 \%$ reduction in odds of observing speeds greater than $56.33 \mathrm{~km} / \mathrm{hr}(35 \mathrm{mi} / \mathrm{hr})$. These results confirm the inference from the descriptive analysis; specifically, the percentage of vehicles traveling in the higher speed bins decreased after the reduction. 
SE 114th Ave, North of Boise St. (37) -

SE 116th Ave, North of Boise St. (38) -

SE 25th Ave, North of Harrison St. (31) -

N Campbell Ave, South of N Simpson St. (2) NE 80th Ave, South of Clackamas St. (18)

SE Alder St., West of 115th Ave (44) -

SW Twombly Ave, West of Hamilton St. (59) -

SE Franklin St., East of 26th Ave (48) -

NE Alberta St., West of 80 th Ave (24) -

SE 48th Ave, South of Hawthorne Blvd. (33)

SE Cora St., East of 138th Ave (46) -

NE Hancock St., West of 15th Ave (27) -

NW Kearney St., West of 22nd Ave (29) -

NE 62nd Ave, South of Hancock St. (16)-

NE 109th Ave, North of Hassalo St. (19) -

NE 13th Ave, North of Failing St. (11) -

SE 113th Ave, North of Pine St. (36) -

SE 125th Ave, North of Clinton Ct. (39)-

NE 37th Ave, North of Broadway (14) -

SE Brooklyn St., East of 21st Ave (45) -

SE 71st Ave, North of Reedway St. (34) -

SE Reynolds St., East of 12th Ave (52) -

SE 23rd Ave, South of Reedway St. (30)

NE 74th Ave, North of Fremont St. (17) -

NE Rosa Parks Way, East of 17th Ave (28) -

SE 34th Ave, South of Cora St. (32)-

N Midway Ave, South of Mears St. (5) -

SE Maple Ave, South of Hawthorne Blvd. (49) -

SE Francis St., East of 33rd Ave (47) -

SW Kingston Ave, South of SW Tichner Dr. (56) -

N Oregonian Ave, South of Mears St. (7) -

NE Fremont St., East of 148th Ave (25) -

N Edison St., West of N Charleston Ave (3)

N Kellog St. East-West Bound North of St. Louis Ave (4) -

NE 114th Ave, South of Schuyler St. (20)-

N Minnesota Ave, South of Simpson St. (6) -

SW Davenport St., East of Robins Crest Dr. (55) -

SE 80th Ave, South of Taylor Ct. (35)

NE 52nd Ave, North of Hassalo St. (15) -

SE 141st Ave, North of Woodward St. (41) -

N Schofield St., West of Denver Ave (8) -

NE 117th Ave, North of Eugene St. (21) -

SW Troy St., East of 27th Ave (58)

SE Morrison St., West of 36th Ave (50) -

SE 168th Ave, South of Alder St. (42) -

NE Graham St., West of Rodney Ave (26) -

SE Alder St., East of 82nd Ave (43)-

N Bowdoin Ave, East of Westanna Ave (1) -

SE Yamhill St., West of 90th Ave (53) -

NE 14th Ave, South of Fremont St. (12) -

SW Ridge Dr., South of Evelyn St. (57) -

SE 135th Ave, South of Sherman St. (40)-

SE Pine St., East of 12th Ave (51) -

NE Ainsworth St. (Westbound), East of 10th Ave (23)-

NE 9th Ave, North of Thompson St. (10)

NE Ainsworth St. (Eastbound), East of 10th Ave (22) -

SE 39th Dr., South of Lee St. (54) -

N Willamette Blvd., West of Charleston Ave (9) -

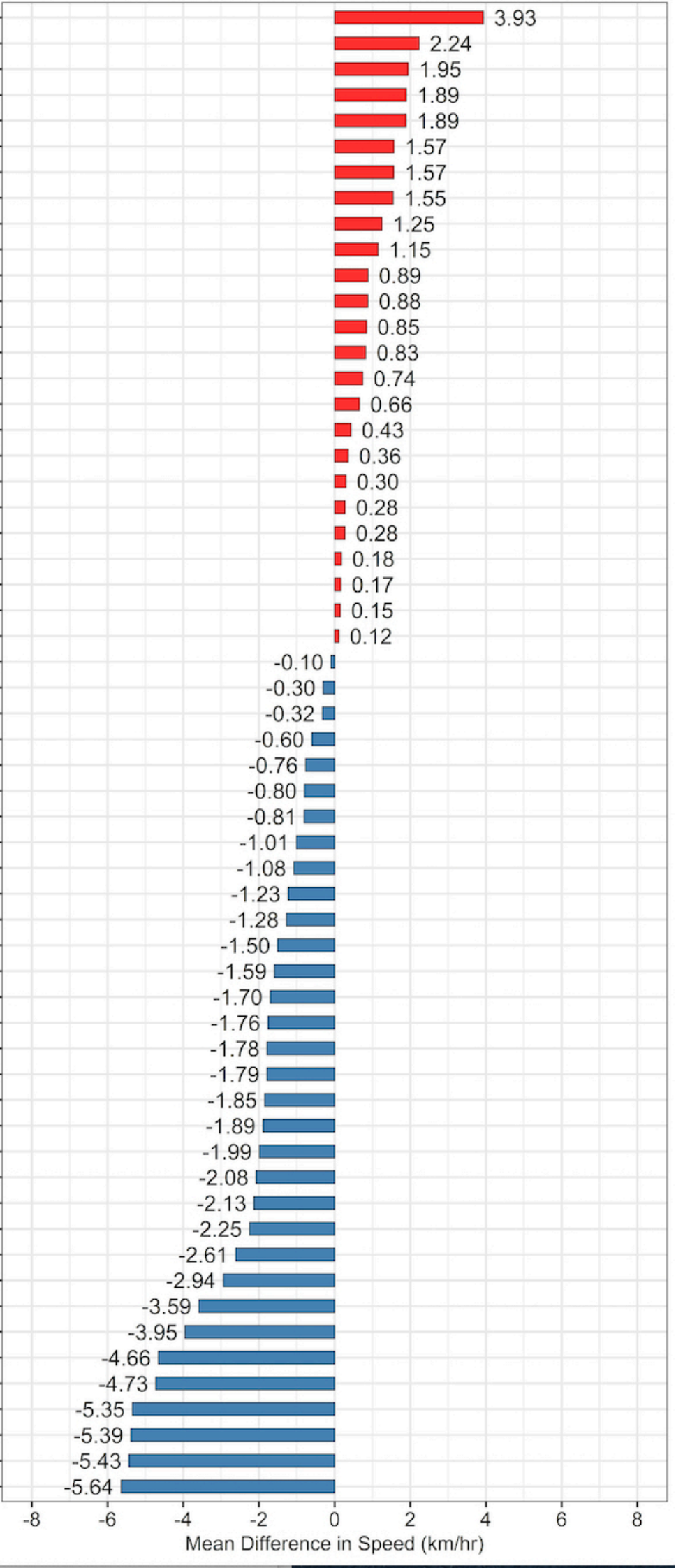

Figure 2. Change in Mean Speeds $(\mathrm{km} / \mathrm{hr})$ by Site 
SE 116th Ave, North of Boise St. (38) -

NE Alberta St., West of 80th Ave (24)

NE Fremont St., East of 148th Ave (25)

N Campbell Ave, South of N Simpson St. (2)

SE 114th Ave, North of Boise St. (37)

SE Cora St., East of 138th Ave (46)

SE 125th Ave, North of Clinton Ct. (39)

NE 37th Ave, North of Broadway (14)

SE Alder St., West of 115th Ave (44)

SE 113th Ave, North of Pine St. (36)

N Midway Ave, South of Mears St. (5) -

NE 62nd Ave, South of Hancock St. (16) -

SE 71st Ave, North of Reedway St. (34) -

SE Franklin St., East of 26th Ave (48) -

SE Morrison St., West of 36th Ave (50)

NE Hancock St., West of 15th Ave (27)

NE 74th Ave, North of Fremont St. (17)

SW Twombly Ave, West of Hamilton St. (59)

NE 14th Ave, South of Fremont St. (12)

SE 48th Ave, South of Hawthorne Blvd. (33)

NW Kearney St., West of 22nd Ave (29)

NE 80th Ave, South of Clackamas St. (18) -

SE Maple Ave, South of Hawthorne Blvd. (49)-

NE 13th Ave, North of Failing St. (11)

SE Alder St., East of 82nd Ave (43)

NE Rosa Parks Way, East of 17th Ave (28)

N Kellog St. East-West Bound North of St. Louis Ave (4)

$\mathrm{N}$ Edison St., West of N Charleston Ave (3)

NE 52nd Ave, North of Hassalo St. (15)

SE 25th Ave, North of Harrison St. (31) -

SE Reynolds St., East of 12th Ave (52)

NE Graham St., West of Rodney Ave (26) -

N Bowdoin Ave, East of Westanna Ave (1)

SE Brooklyn St., East of 21st Ave (45)

NE 109th Ave, North of Hassalo St. (19)-

N Oregonian Ave, South of Mears St. (7) SW Kingston Ave, South of SW Tichner Dr. (56)

SE 80th Ave, South of Taylor Ct. (35)

NE 9th Ave, North of Thompson St. (10)-

SE 168th Ave, South of Alder St. (42)

N Schofield St., West of Denver Ave (8)

SE Pine St., East of 12th Ave (51)

SE 23rd Ave, South of Reedway St. (30)

SW Davenport St., East of Robins Crest Dr. (55) -

NE 114th Ave, South of Schuyler St. (20)

SE Francis St., East of 33rd Ave (47)

NE 117th Ave, North of Eugene St. (21) -

SW Troy St., East of 27th Ave (58)

SE 141st Ave, North of Woodward St. (41) -

SE Yamhill St., West of 90th Ave (53)

SW Ridge Dr., South of Evelyn St. (57) -

N Minnesota Ave, South of Simpson St. (6) N Willamette Blvd., West of Charleston Ave (9) -

SE 135th Ave, South of Sherman St. (40)

SE 34th Ave, South of Cora St. (32) -

SE 39th Dr., South of Lee St. (54)

NE Ainsworth St. (Eastbound), East of 10th Ave (22)
NE Ainsworth St. (Westbound), East of 10th Ave (23)

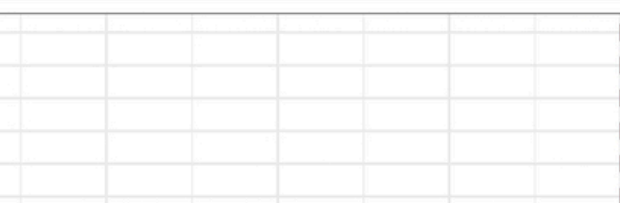

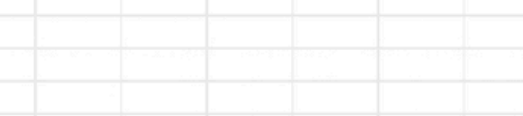

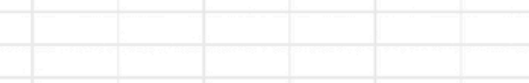

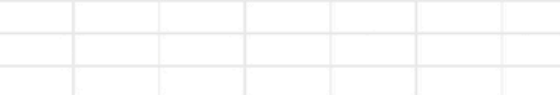

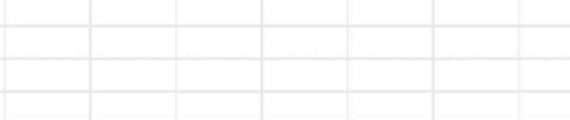

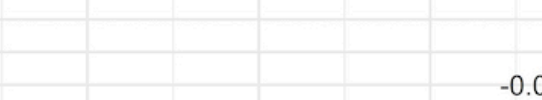

$-0.00 \%$

$-0.04 \%$ ।

$-0.06 \%$

$-0.08 \%$

$-0.09 \%$

$-0.26 \%$ I

$-0.30 \%$

$-0.31 \%$

$-0.32 \%$

$-0.38 \%$

$-0.53 \%$

$-0.61 \%$

$-0.65 \%$ ㅁ

$-0.68 \%$

$-0.73 \%$

$-0.76 \%$

$-0.80 \%$ ㅁ

$-0.88 \%$

$-0.97 \%$

$-0.98 \%$

$-0.98 \%$

$-1.17 \%$

$-1.24 \%$

$-1.40 \%$

$-1.50 \%$

$-1.72 \%$

$-1.80 \%$

$-1.81 \%$

$-2.08 \%$

$-2.33 \%$

$-3.19 \%$

$-3.75 \%$

$-4.11 \%$

$-6.00 \%$

$-6.09 \%$

$-8.43 \%$

$-11.12 \%$

$-21.27 \%$

$-28.96 \%$
$-29.45 \%$

$-30 \%$

$-20 \%$

$-10 \%$

$0 \%$

$8 \mathrm{~km} / \mathrm{hr}$
$4.36 \%$

$1.84 \%$

$1.80 \%$

$1.53 \%$

$1.52 \%$

$1.33 \%$

$0.72 \%$

$0.47 \%$

$0.47 \%$

- $0.45 \%$

$0.32 \%$

$0.29 \%$

$0.24 \%$

$0.22 \%$

$0.21 \%$

$0.14 \%$

$0.08 \%$

$0.05 \%$

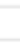

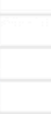

1

(1)

Figure 3. Change in Percent of Vehicles With Speed Greater Than $48.28 \mathrm{~km} / \mathrm{hr}(30 \mathrm{mi} / \mathrm{hr})$ by Site 
Table 2. Log-Linear Regression Model Specifications for Observed Speed

\begin{tabular}{|c|c|c|c|}
\hline Variable & Coefficient & Std. Error & $p$-value \\
\hline Constant & 2.341 & 0.020 & $<0.0001$ \\
\hline \multicolumn{4}{|l|}{ Before/After Period } \\
\hline 1 if after speed reduction, 0 if before & -0.010 & 0.001 & $<0.0001$ \\
\hline \multicolumn{4}{|l|}{ Time-of-Day } \\
\hline 1 if $6: 00$ a.m. to $10: 00$ a.m., 0 otherwise & -0.007 & 0.001 & $<0.0001$ \\
\hline 1 if $4: 00$ p.m. to $8: 00$ p.m., 0 otherwise & 0.028 & 0.005 & $<0.0001$ \\
\hline \multicolumn{4}{|l|}{ Day-of-Week } \\
\hline 1 if Wednesday, 0 otherwise & 0.056 & 0.002 & $<0.0001$ \\
\hline 1 if Thursday, 0 otherwise & 0.025 & 0.002 & $<0.0001$ \\
\hline 1 if Friday, 0 otherwise & 0.016 & 0.002 & $<0.0001$ \\
\hline 1 if Weekend, 0 otherwise & -0.081 & 0.003 & $<0.0001$ \\
\hline \multicolumn{4}{|l|}{ Roadway Characteristics } \\
\hline Natural logarithm of surface width & 0.088 & 0.005 & $<0.0001$ \\
\hline Natural logarithm of pavement condition index & 0.107 & 0.002 & $<0.0001$ \\
\hline Curb height & -0.011 & 0.000 & $<0.0001$ \\
\hline
\end{tabular}


Table 3. Binary Logit Model Specifications of Speeds Greater Than $40.23 \mathrm{~km} / \mathrm{hr}, 48.28 \mathrm{~km} / \mathrm{hr}$, and $56.33 \mathrm{~km} / \mathrm{hr}$

\begin{tabular}{|c|c|c|c|c|c|c|c|c|c|c|c|c|}
\hline \multirow{2}{*}{ Variable } & \multicolumn{4}{|c|}{ Greater Than $40.23 \mathrm{~km} / \mathrm{hr}$} & \multicolumn{4}{|c|}{ Greater Than $48.28 \mathrm{~km} / \mathrm{hr}$} & \multicolumn{4}{|c|}{ Greater Than $56.33 \mathrm{~km} / \mathrm{hr}$} \\
\hline & Coefficient & $\begin{array}{c}\text { Std. } \\
\text { Error }\end{array}$ & $p$-value & $\mathrm{OR}^{\mathrm{a}}$ & Coefficient & $\begin{array}{c}\text { Std. } \\
\text { Error }\end{array}$ & $p$-value & $\mathrm{OR}^{\mathrm{a}}$ & Coefficient & $\begin{array}{c}\text { Std. } \\
\text { Error }\end{array}$ & $p$-value & $\mathrm{OR}^{\mathrm{a}}$ \\
\hline Constant & -5.256 & 0.167 & $<0.0001$ & & -9.728 & 0.329 & $<0.0001$ & & -12.289 & 0.829 & $<0.0001$ & \\
\hline \multicolumn{13}{|l|}{ Before/After Period } \\
\hline 1 if after speed reduction, 0 before & -0.173 & 0.011 & $<0.0001$ & 0.841 & -0.409 & 0.020 & $<0.0001$ & 0.664 & -0.686 & 0.054 & $<0.0001$ & 0.504 \\
\hline \multicolumn{13}{|l|}{ Time-of-Day } \\
\hline 1 if $6: 00$ a.m. to $10: 00$ a.m., 0 otherwise & -0.090 & 0.011 & $<0.0001$ & 0.914 & -0.204 & 0.021 & $<0.0001$ & 0.816 & -0.373 & 0.056 & $<0.0001$ & 0.688 \\
\hline 1 if $4: 00$ p.m. to $8: 00$ p.m., 0 otherwise & 0.181 & 0.037 & $<0.0001$ & 1.199 & 0.318 & 0.059 & $<0.0001$ & 1.374 & 0.796 & 0.110 & $<0.0001$ & 2.217 \\
\hline \multicolumn{13}{|l|}{ Day-of-Week } \\
\hline 1 if Wednesday, 0 otherwise & 0.543 & 0.014 & $<0.0001$ & 1.721 & 0.810 & 0.030 & $<0.0001$ & 2.247 & 0.784 & 0.082 & $<0.0001$ & 2.191 \\
\hline 1 if Thursday, 0 otherwise & 0.433 & 0.014 & $<0.0001$ & 1.542 & 0.938 & 0.028 & $<0.0001$ & 2.555 & 1.094 & 0.075 & $<0.0001$ & 2.985 \\
\hline 1 if Friday, 0 otherwise & 0.373 & 0.017 & $<0.0001$ & 1.452 & 1.182 & 0.031 & $<0.0001$ & 3.261 & 1.419 & 0.077 & $<0.0001$ & 4.132 \\
\hline 1 if Weekend, 0 otherwise & -0.757 & 0.028 & $<0.0001$ & 0.469 & -0.985 & 0.070 & $<0.0001$ & 0.374 & -1.177 & 0.197 & $<0.0001$ & 0.308 \\
\hline \multicolumn{13}{|l|}{ Roadway Characteristics } \\
\hline Natural logarithm of surface width & 0.348 & 0.041 & $<0.0001$ & 1.417 & 0.408 & 0.077 & $<0.0001$ & 1.504 & 0.162 & 0.189 & 0.390 & 1.176 \\
\hline Natural logarithm of $\mathrm{PCl}^{\mathrm{b}}$ & 0.734 & 0.018 & $<0.0001$ & 2.084 & 1.268 & 0.040 & $<0.0001$ & 3.554 & 1.568 & 0.108 & $<0.0001$ & 4.797 \\
\hline Curb height & -0.057 & 0.003 & $<0.0001$ & 0.945 & -0.015 & 0.006 & 0.011 & 0.985 & 0.040 & 0.015 & 0.009 & 1.040 \\
\hline
\end{tabular}

a estimated odds ratio

${ }^{\mathrm{b}}$ pavement condition index

* $40.23 \mathrm{~km} / \mathrm{hr}=25 \mathrm{mi} / \mathrm{hr} ; 48.28 \mathrm{~km} / \mathrm{hr}=30 \mathrm{mi} / \mathrm{hr} ; 56.33 \mathrm{~km} / \mathrm{hr}=35 \mathrm{mi} / \mathrm{hr}$ 


\section{Acknowledgments}

The authors want to acknowledge the Portland Bureau of Transportation (PBOT) for funding this work and providing the necessary data. The authors also want to thank Matthew Kelly of PBOT for his support duirng the project.

Submitted: December 04, 2021 AEDT, Accepted: January 19, 2022 AEDT

This is an open-access article distributed under the terms of the Creative Commons Attribution 4.0 International License (CCBY-SA-4.0). View this license's legal deed at https://creativecommons.org/ licenses/by-sa/4.0 and legal code at https://creativecommons.org/licenses/by-sa/4.0/legalcode for more information. 


\section{REFERENCES}

Bornioli, Anna, Isabelle Bray, Paul Pilkington, and Emma L. Bird. 2018. "The Effectiveness of a 20 mph Speed Limit Intervention on Vehicle Speeds in Bristol, UK: A Non-Randomised Stepped Wedge Design." Journal of Transport and Health 11 (December): 47-55. https://doi.org/10.1016/ j.jth.2018.09.009.

Fitzpatrick, Kay, Paul Carlson, Marcus Brewer, and Mark Wooldridge. 2001. "Design Factors That Affect Driver Speed on Suburban Streets." Transportation Research Record: Journal of the Transportation Research Board 1751 (1): 18-25. https://doi.org/10.3141/1751-03.

Giles, Margaret J. 2004. "Driver Speed Compliance in Western Australia: A Multivariate Analysis.” Transport Policy 11 (3): 227-35. https://doi.org/10.1016/j.tranpol.2003.11.002.

$\mathrm{Hu}$, Wen, and Jessica B Cicchino. 2020. "Lowering the Speed Limit from 30mph to $25 \mathrm{mph}$ in Boston: Effects on Vehicle Speeds.” Injury Prevention 26 (2): 99-102. https://doi.org/10.1136/ injuryprev-2018-043025. 